\title{
Social Media Use During COVID-19: Real and Fake News?
}

\author{
Maarij Malik¹, Mohammad Aadil Qamar², Syed Shabbir Afzal2*, Sohaib Tousif², Farheen Malik², Khizr Asif Bhura² \\ and Khizer Shamim² \\ ${ }^{1}$ Aga Khan University, Karachi, Pakistan \\ 'Ziauddin University, Karachi, Pakistan \\ ${ }^{3}$ Dow Medical College, DUHS, Karachi, Pakistan
}

\begin{abstract}
The outbreak of COVID-19 led the world into disarray as people were forced to isolate themselves. Being known to be social animals, humans developed a coping mechanism: Increased use of social media to bridge the physical distance. This review article aims to assess the impact, both positive and negative, of increased social media usage on lives. The Pandemic made it clear that whilst social media is an important outlet for information, it is also the culprit since most of the websites spread false/fabricated information to increase their viewership. As a result, it amplified anxiety and depression in people's lives. Tools to monitor social media information are a necessity to outweigh its drawbacks. This includes filtering misinformation, providing mental health support, and encouraging people to refrain from spreading dubious content that lacks strong evidence.
\end{abstract}

Keywords: COVID-19, social media, mental health, anxiety, depression, internet.

\section{INTRODUCTION}

Originating from Wuhan, China, the COVID-19 disease spread globally in a matter of months making millions of people its victims. As a result, the World Health Organization (WHO) declared it as a pandemic [1]. Apart from the loss of lives, the significant emotional trauma it caused to numerous people throughout the world is unparalleled to any other pandemic [2]. As the COVID-19 spread in an uncontrolled manner, the WHO advised people to self-isolate to socially distance themselves from others, bringing about a massive lifestyle change. Humans being social animals developed a coping mechanism involving the use of social media to overcome the physical distance. The change has been abrupt and created a sense of uncertainty. As people did not know how long they will have to stay in self-isolation and even the rules for social distancing kept changing. As a result, negatively impacting the physical and mental health of the people [3].

\section{THE SURGE IN SOCIAL MEDIA}

As the world was going under lockdown, it became crucial to gain information and updates regarding the pandemic specifically related to the virus, its treatment, and complications. Subsequently, there was a surge in the use of social media websites: especially Facebook and Twitter for obtaining information. On the downside, this led to the spread of misinformation about COVID-19 at unprecedented levels [4].

Users of different online platforms had different motivations to use the internet. As many people were

\footnotetext{
*Corresponding author: Syed Shabbir Afzal, Ziauddin University, Karachi, Pakistan; Email: syedshabbirafzal6@gmail.com

Received: August 23, 2021; Revised: September 26, 2021; Accepted: September 30, 2021 DOI: https://doi.org/10.37184/lnjpc.2707-3521.3.14
}

staying indoors with little to nothing to do, some wanted to get entertainment by using online platforms only, others searched to get the information regarding the virus, to know about their family and friends' social activities [5, 6]. Hence, social media saw a peaked increase of $61 \%$ in usage, with WhatsApp usage increased to $50 \%$ in countries devastated by the virus.

According to google trends for the USA, during the lockdown days, Coronavirus was the most searched topic on google search engine and after the first confirmed case in the USA led to the rise in $52 \%$ of searches related to 'Coronavirus symptoms and treatment' [5].

This review aims to discuss the effects and implications of increased social media usage and finding possible links between social media use and mental healthrelated issues during the pandemic.

\section{SPREAD OF MISINFORMATION}

In this era of the internet, social media plays a pivotal role in spreading information worldwide and updating people on current situations across the globe. While social media is the relatively leading source of information about the pandemic, it is also the number one source of false information. The non-health personals and the scientific community must be very aware of the information they are reading on the internet as most of it can contain false information.

Misinformation can not only be dangerous to one's physical wellbeing but also influences people's beliefs and overall decisions [7]. A study regarding social media as a provider of information found that $59 \%$ of US adults believe that information available on social media platforms was inaccurate. It is found that only $1.8 \%$ of websites had a HONcode seal. The DISCERN score showed that $70.0 \%$ of the websites were evaluated as 
having a low score, and none were rated as having a high score [8].

The current pandemic faces significant documentation and considerable influence through social media [7] that was seen with the previous pandemics, such as the $\mathrm{H} 1 \mathrm{~N} 1$ virus, Ebola virus, and Zika virus leading towards the spread of false information, which enhanced the anxiety and stress level amongst the individuals [7].

\section{WHAT HAPPENED?}

Initially, social media running agencies were not held accountable for the content which they posted. Subsequently, WHO and many other public organizations took over social platforms to curb misleading information.

A study was conducted on Twitter related to Coronavirus and was assessed individually for misinformation by comparing them with verified and peer-reviewed research. Around $24.8 \%$ of tweets were misinformation, and $17.4 \%$ were not verifiable. Misinformation came higher from tweets of informal accounts and groups, $33.8 \%$. Similarly, tweets from unverified Twitter account contained higher misinformation $31.0 \%$ than verified accounts $12.6 \%$. The tweets from healthcare and medical professionals contained the lowest rate of unverifiable information $12.3 \%$.

The conclusive crux of this research was that participants revealed how false information received from online sources and social media apps are hard to differentiate from the truth. For instance, the false claim that COVID-19 is non-lethal had caused people to roam freely without masks or any heed towards precautionary measures, resulting in them not only putting their own lives at risk but anyone they might encounter. All in all, most participants believed that social media is not the most credible, reliable, or even entirely valid source for updates.

Two studies were conducted, with the first testing for the dissociation between accuracy judgments and sharing intentions when participants evaluated a set of true and false headlines about COVID-19. The first study showed that veracity had a much more significant impact on accuracy judgments than on sharing intentions. In particular, for false headlines, $32.4 \%$ more people were willing to share the headlines, rating them as accurate [9].

Mosley, Pennycook, and Rand 2020 also showed a positive interaction between headline veracity and treatment, which increased sharing discernment. The participants in treatment proved that sharing intentions for true headlines were significantly higher than for false headlines. This suggested that the very tendency to be distracted from accuracy is the key factor preventing people from considering accuracy on social media [9].

\section{WHAT TO DO?}

Research has become a necessity, not only to counter the spread of the disease itself but the misinformation related to it [7].

Furthermore, the public should act responsibly and refrain from posting such content that can enhance anxiety and depression amongst people. Even a conspiracy summed with fake news has a significant impact on people's health around the world [7]. It is up to the public, to correct the public, and on a personal level [9].

\section{ANXIETY}

At the beginning of 2020 , the news of the COVID outbreak rapidly flourished through social media and newspapers. Quite less was known about the virus itself back then.

A cross-sectional study was conducted in China during February 2020 on individuals aged $\geq 18$ years old. The prevalence of anxiety was found to be $22.6 \%$ in the COVID-19 outbreak in Wuhan, China. More than $80 \%$ of participants reported frequent exposure to social media. Thus, odds of anxiety were greater with social media exposure or usage compared with fewer SMEs. All of these findings led to the implication that the government should take adequate measures to work on the problems of mental health prevalent among the individuals during the pandemic due to the news circulating over social media [10].

Another study was conducted in the epicenter of the virus (Wuhan) on the probable risk factors including social media exposure on the community-based adults and the health care professionals. One-fifth of the respondents reported probable anxiety and probable depression. Likewise, health care professionals, onefifth of surveyed professionals reported probable anxiety or probable depression. The data suggests that about one-third of the community-based adults and health professionals spent their time $\geq 2$ hours daily on social media scrolling through the news of COVID. Thus, the study predicted a positive correlation between social media use and its effects on mental health [11].

Similar research was conducted on social media users in Iraq, where the highest proportion of participants (76.4\%) had heard and seen news related to health, while only $(0.6 \%)$ people had seen the news on technology. This concluded that most health crises in individuals were increasing by the use of social media [9].To assess the speed of the spread of information on social media an interview was conducted on 13 active social media users based on extended questions and it was found that all of them were religiously following the pandemic updated on various platforms of social media [7].

\section{DEPRESSION}

The pandemic was also a significant cause of depression. According to a study, it has been shown that the odds of depression were frequent amongst those who age 2130 years old and 31-40 years while being lower among 
students at college and master education than children in middle school [12]. The increased likelihood of developing depression is significantly intensified by the decrease in self-rated health which is why higher rates of SME resulted in higher odds of depression. This emphasizes the traumatizing effect of constant contact with infected individuals and less frequent SMEs regarding news and updates of the virus [10]. As lockdowns are imposed and relatives are separated, adolescents with a record of depression are left unprotected to prolonged mental enduring in association with unforeseen bereavement [13]. For example, there was a $30 \%$ increase in elderly suicide during the SARS epidemic in the early 2000s and around $50 \%$ of recovered patients had persistent anxiety [14]. Patients who had recovered or experienced sudden bereavement were at great risk of PTSD and depression [14].

As confinement within houses was imposed, an increase in domestic abuse occurs while the social vulnerability is at an all-time high. In a survey conducted among Chinese adolescents during the COVID-19 outbreak, depression was rampant in children aged 12-18 [11]. In a time of both financial and social defenselessness, adapting capacities and accessible psychological aid are variables related to pre-adult mental wellbeing [10]. In addition to the risk of abuse, another disastrous consequence of the petrifying pandemic was loneliness and social isolation which correlated with anxiety, depression, self-harm, and suicide attempts, leading to a scarring negative effect on psychological wellbeing [10]. About the profound effect of the lockdown, disorders such as PTSD, anxiety disorders, and grief-related disorders have resulted from fear of the pandemic [13]. In the case of bereavement, parental death is a risk factor for a major depressive disorder in adolescents as well as physical and emotional separation from loved ones [11]. Precautionary lockdown causes emotional distress in parents which may result in cases of depression for both them and their children [11].
There is an established high prevalence of mental health problems that appear during an outbreak [12]. Stressful events, such as a pandemic and restrictive lockdown are risk factors for adolescent suicidality [11]. Due to the heightened depression, stress as a consequence of social isolation and concerns about financial distress was reported in a survey done by [4, 14].

To combat the depression' infodemic' that has surged cases of mental disorders is by filtering and monitoring misinformation to decrease unnecessary nervousness and fear that consequently results in psychological damage. Even though the Chinese government has offered mental health facilities including hotlines, online consultation and courses, and outpatient consultation, more focus is needed on depression and anxiety [12].

\section{POSITIVE ROLE}

Despite its many demerits, the potency of technology and all the benefits of distanced social contact it brings to people during an urban calamity such as the COVID-19 pandemic are worthy of notice.

Table 1 shows one such example in the well-known WeChat application, with a $90 \%$ prevalence rate in the major cities of China. This makes it the application of choice for the conduction of online surveys to gather information for research purposes while maintaining social distancing.

During the lockdown in China, WeChat was widely used in the residential complexes of Wuhan where online groups were formed including at least one member from each household. These groups proved very useful in facilitating communications, providing support to fellow residents, and organizing bulk purchases of necessary items.

Social media also played a vital role in mitigating the adverse effects of the pandemic and the inevitable social distancing it brings with it. As mentioned before, the prevalence of anxiety and depression increased

\section{SOLUTION}

Table 1: Study characteristics.

\begin{tabular}{|c|c|c|c|c|c|c|c|}
\hline $\begin{array}{l}\text { Author Name, } \\
\text { Year, Location }\end{array}$ & Population & $\begin{array}{c}\text { Total } \\
\text { (n) }\end{array}$ & $\begin{array}{l}\text { Males } \\
\text { (n) }\end{array}$ & $\begin{array}{l}\text { Age } \\
\text { (Years } \\
\text { old) }\end{array}$ & $\begin{array}{l}\text { Main Findings of the } \\
\text { Study }\end{array}$ & $\begin{array}{l}\text { Social } \\
\text { Media as } \\
\text { a Risk } \\
\text { Factor }\end{array}$ & $\begin{array}{l}\text { Additional Findings in the } \\
\text { Study }\end{array}$ \\
\hline $\begin{array}{l}\text { D o m e } n \text { i c o } \\
\text { Cucinotta and } \\
\text { Maurizio Vanelli } \\
\text { 2020, March } 19 \\
\text { China }\end{array}$ & $\begin{array}{l}\text { Older adults with } \\
\text { comorbidities } \\
\text { People with serious } \\
\text { chronic conditions } \\
\text { like Heart disease, } \\
\text { Diabetes, and lung } \\
\text { disease }\end{array}$ & - & - & - & $\begin{array}{l}\text { Mean incubation period: } \\
5.2 \text { days [CI, } 4.1 \text { to } 7.0 \\
\text { days] }\end{array}$ & - & $\begin{array}{l}\text { Alarge proportion of complications } \\
\text { like septic shock and organ failure } \\
\text { with Covid-19 related critical } \\
\text { illness, causing higher mortality. }\end{array}$ \\
\hline $\begin{array}{l}\text { Bu Zhong et al. } \\
2020 \text {, August } 15 \\
\text { Wuhan, China }\end{array}$ & $\begin{array}{l}\text { Residents of all } \\
7 \text { urban districts } \\
\text { of Wuhan with } \\
\text { no prior history } \\
\text { of any traumatic } \\
\text { or depressive } \\
\text { disorders }\end{array}$ & 320 & 118 & $\begin{array}{l}\text { Mean } \\
\text { age: } \\
45.57 \\
\text { SD: } \\
14.552\end{array}$ & $\begin{array}{l}\text { Excessive use of social } \\
\text { media has proven to be } \\
\text { beneficial in obtaining, } \\
\text { informational, emotional } \\
\text { and peer support, } \\
\text { however, it has also had } \\
\text { an impact on mental } \\
\text { health. }\end{array}$ & $+/-$ & $\begin{array}{l}\text { The educational background } \\
\text { did not affect the prevalence } \\
\text { of depression and secondary } \\
\text { trauma } \\
\text { Known death cases amongst } \\
\text { neighbors, relatives, etc. led to } \\
\text { higher chances of developing } \\
\text { depression. }\end{array}$ \\
\hline
\end{tabular}




\begin{tabular}{|c|c|c|c|c|c|c|c|}
\hline $\begin{array}{l}\text { Author Name, } \\
\text { Year, Location }\end{array}$ & Population & $\begin{array}{c}\text { Total } \\
(\mathrm{n})\end{array}$ & $\begin{array}{l}\text { Males } \\
\text { (n) }\end{array}$ & $\begin{array}{l}\text { Age } \\
\text { (Years } \\
\text { old) }\end{array}$ & $\begin{array}{l}\text { Main Findings of the } \\
\text { Study }\end{array}$ & $\begin{array}{l}\text { Social } \\
\text { Media as } \\
\text { a Risk } \\
\text { Factor }\end{array}$ & $\begin{array}{l}\text { Additional Findings in the } \\
\text { Study }\end{array}$ \\
\hline $\begin{array}{l}\text { Teagen Nabity- } \\
\text { Grover et al. } \\
\text { 2020, June } 28 \\
\text { Global }\end{array}$ & Social media users & - & - & - & $\begin{array}{l}\text { The pandemic has } \\
\text { changed how people } \\
\text { interact via social } \\
\text { media. Information, } \\
\text { which was previously } \\
\text { disclosed easily, is now } \\
\text { kept a secret (outside- } \\
\text { in), whereas some } \\
\text { topics have now been } \\
\text { shared publicly that } \\
\text { were previously private } \\
\text { (inside-out). }\end{array}$ & + & $\begin{array}{l}\text { Social media usage has seen } \\
\text { a surge of } 61 \% \text { during the } \\
\text { pandemic. } \\
\text { In early } 2020 \text {, US children (aged } \\
4-15 \text { ), spent } 13 \% \text { more time on } \\
\text { YouTube and } 16 \% \text { more time on } \\
\text { TikTok. }\end{array}$ \\
\hline $\begin{array}{l}\text { Sheera Frenkel et } \\
\text { al. 2020, March } 8 \\
\text { Global }\end{array}$ & $\begin{array}{l}\text { Normal individuals } \\
\text { using social media } \\
\text { as a source of } \\
\text { information }\end{array}$ & - & - & - & $\begin{array}{l}\text { Despite measures by } \\
\text { social media platforms, } \\
\text { users have chosen to } \\
\text { spread misinformation } \\
\text { regarding the virus. }\end{array}$ & + & $\begin{array}{l}\text { Hackers were found using } \\
\text { websites claiming to have } \\
\text { information regarding the virus as } \\
\text { a trap to lure and steal personal } \\
\text { information. }\end{array}$ \\
\hline $\begin{array}{l}\text { Ana I. Bento et al. } \\
\text { 2020, May } 4 \\
\text { USA }\end{array}$ & $\begin{array}{lr}\text { Normal individuals } \\
\text { searching r ror } \\
\text { COVID-19 related } \\
\text { information }\end{array}$ & - & - & - & $\begin{array}{l}\text { First state COVID-19 } \\
\text { case announcements } \\
\text { resulted in a massive } \\
\text { increase in searches } \\
\text { related to information } \\
\text { about the epidemic e.g. } \\
\text { by } 36 \% \text { the next day } \\
\text { after the announcement. }\end{array}$ & + & $\begin{array}{l}\text { Policymakers can use the } \\
\text { findings of this study to avoid risk } \\
\text { by ensuring early disclosure of } \\
\text { information regarding first cases } \\
\text { and first deaths. }\end{array}$ \\
\hline $\begin{array}{l}\text { A.K.M. Najmul } \\
\text { Islam et al. 2020, } \\
\text { July } 12 \text { Bangladesh }\end{array}$ & $\begin{array}{l}\text { Social media users } \\
\text { in Bangladesh }\end{array}$ & 433 & 268 & $18-25$ & $\begin{array}{l}\text { Deficient self-regulation } \\
\text { (DS-R), exploration, } \\
\text { and self-promotion were } \\
\text { the major factors for } \\
\text { the spread of unverified } \\
\text { information. }\end{array}$ & + & $\begin{array}{l}\text { Social media fatigue (SMF), self- } \\
\text { promotion, and entertainment } \\
\text { have a positive effect on sharing } \\
\text { unverified information } \\
\text { Whereas religiosity and } \\
\text { exploration have negative effects. }\end{array}$ \\
\hline $\begin{array}{l}\text { Brindha Duraisamy } \\
\text { et al. } 2020 \text { April } \\
\text { India }\end{array}$ & $\begin{array}{l}\text { Well-e d u c a t e d } \\
\text { individuals, active } \\
\text { on social media }\end{array}$ & 13 & - & - & $\begin{array}{l}\text { Even though the } \\
\text { government has tried } \\
\text { to direct the public } \\
\text { towards reliable sources } \\
\text { of information, the } \\
\text { pandemic has still been } \\
\text { outpaced by the spread } \\
\text { of misinformation related } \\
\text { to it. }\end{array}$ & + & $\begin{array}{l}\text { In a country like India, where } \\
\text { Wikipedia, a site where anyone } \\
\text { can edit information, is still the } \\
\text { most visited site, it is imperative } \\
\text { to find reliable alternate sources. }\end{array}$ \\
\hline $\begin{array}{l}\text { Jose Yunam Cuan- } \\
\text { Baltazar et al. 2020, } \\
\text { April } 9 \text { University } \\
\text { Anáhuacr Puebla } \\
\text { at Tlaxcalancingo, } \\
\text { Puebla, México }\end{array}$ & $\begin{array}{l}110 \text { websites that } \\
\text { appeared as part of } \\
\text { a search result }\end{array}$ & - & - & - & $\begin{array}{l}\text { Out of the } 110 \text { websites, } \\
\text { only } 2 \text { had an HONcode } \\
\text { seal, } 43 \text { did not meet any } \\
\text { of the JAMA benchmark } \\
\text { criteria and } 11 \text { had all } \\
\text { four criteria. } \\
\text { DISCERN score showed } \\
77 \text { of the } 110 \text { websites } \\
\text { were reported to have } \\
\text { a low score and none } \\
\text { achieved a high score. }\end{array}$ & + & - \\
\hline $\begin{array}{l}\text { Gordon Pennycook } \\
\text { et al. } \\
\text { USA }\end{array}$ & $\begin{array}{l}\text { Adults recruited } \\
\text { online }\end{array}$ & 1709 & 742 & $46-47$ & $\begin{array}{l}\text { In study } 1 \text {, participants } \\
\text { were far more likely to } \\
\text { share false information } \\
\text { than in study } 2 \text {. The } \\
\text { reason for this is that } \\
\text { participants in study } 2 \\
\text { were subtly primed about } \\
\text { assessing the accuracy } \\
\text { of the information before } \\
\text { sharing. }\end{array}$ & + & $\begin{array}{l}\text { Individuals with poor scientific } \\
\text { knowledge showed poor } \\
\text { judgment in deciding if the news } \\
\text { is true or false since they relied } \\
\text { more on their intuition. }\end{array}$ \\
\hline $\begin{array}{l}\text { Araz Ramazan } \\
\text { Ahmad et al. } \\
\text { Iraqi Kurdistan }\end{array}$ & Social media users & 516 & 294 & $18-35$ & $\begin{array}{l}\text { There exists a strong } \\
\text { positiver correlation } \\
(\mathrm{R}=.8701) \text { between } \\
\text { social media and } \\
\text { spreading panic about } \\
\text { COVID-19. }\end{array}$ & + & $\begin{array}{l}\text { This spread has further led to } \\
\text { a psychological impact on the } \\
\text { younger generation, especially in } \\
\text { the } 18-35 \text { age gap. }\end{array}$ \\
\hline
\end{tabular}




\begin{tabular}{|c|c|c|c|c|c|c|c|}
\hline $\begin{array}{l}\text { Author Name, } \\
\text { Year, Location }\end{array}$ & Population & $\begin{array}{c}\text { Total } \\
\text { (n) }\end{array}$ & $\begin{array}{c}\text { Males } \\
\text { (n) }\end{array}$ & $\begin{array}{l}\text { Age } \\
\text { (Years } \\
\text { old) }\end{array}$ & $\begin{array}{l}\text { Main Findings of the } \\
\text { Study }\end{array}$ & $\begin{array}{l}\text { Social } \\
\text { Media as } \\
\text { a Risk } \\
\text { Factor }\end{array}$ & $\begin{array}{l}\text { Additional Findings in the } \\
\text { Study }\end{array}$ \\
\hline $\begin{array}{l}\text { Junling Gao et al. } \\
\text { China }\end{array}$ & Citizens aged $>=18$ & 4827 & 1560 & $\begin{array}{c}32.3 \pm \\
10.0\end{array}$ & $\begin{array}{l}\text { The prevalence of mental } \\
\text { disorders, for example, } \\
\text { Depression, Anxiety, or } \\
\text { the combination of two } \\
\text { markedly increased in } \\
\text { China with an increase } \\
\text { in social media exposure } \\
\text { during the pandemic. } \\
\end{array}$ & + & $\begin{array}{l}\text { A possible reason for the } \\
\text { association between social } \\
\text { media exposure and deteriorating } \\
\text { mental health is the info-demic } \\
\text { that instills fear in people. }\end{array}$ \\
\hline $\begin{array}{l}\text { Michael Y Ni et al. } \\
\text { Wuhan, China }\end{array}$ & $\begin{array}{l}\text { Citizens r aged } \\
>=18 \text { who tested } \\
\text { negative for Covid } \\
\text { were divided } \\
\text { into } 2 \text { groups, } \\
\text { community-based } \\
\text { adults, and Health } \\
\text { professionals, } \\
\text { and enrolled via } \\
\text { WeChat } \\
\end{array}$ & 1577 & 685 & $18-34$ & $\begin{array}{l}\text { Maintaining social } \\
\text { support was associated } \\
\text { with a lower probability of } \\
\text { anxiety and depression. }\end{array}$ & + & $\begin{array}{l}\text { Certain online platforms, for } \\
\text { instance, WeChat can be used } \\
\text { to gather a reliable sample } \\
\text { consisting of community-based } \\
\text { adults and health professionals } \\
\text { during a lockdown state, given } \\
\text { the fact that in-person surveys } \\
\text { are not possible. }\end{array}$ \\
\hline $\begin{array}{ll}\text { Brenda } & \mathrm{K} . \\
\text { Wiederhold }\end{array}$ & - & - & - & - & $\begin{array}{l}\text { Recently, media } \\
\text { companies have noticed } \\
\text { an increase in gaming } \\
\text { data usage, TV usage } \\
\text { and social media usage. } \\
\text { Verizon marked a } 20 \% \\
\text { increase in web traffic in } \\
\text { just a week during March } \\
2020 \text {. }\end{array}$ & + & - \\
\hline
\end{tabular}

SD: Standard Deviation, US: United States of America, PTSD: Post-Traumatic Stress Disorder, Cl: Confidence Interval

significantly; social media emerged as a means of support through online counseling and consultation. Such as Ali Health, Ping a Good Doctor, or WeChat (implemented in China). Aerobic exercises like jogging and cycling have proven to boost cognitive function and self-esteem, hence combating the adverse effects of social withdrawal and symptoms of depression, stress, and anxiety. These can be easily carried out by workout routines available online (live sessions or recorded videos), especially for yoga and aerobics $[10,15]$.

Applications like Facebook and Instagram have enabled the masses, especially children and adolescent teenagers to be connected to their family and friends, as a productive use of their time. The enhancements in technology and the avenues of constant social contact allow students to continue with distance learning via technological devices to keep up with their education [16].

\section{SCREEN TIME}

The onset of the COVID-19 pandemic saw a general trend in the exponential use of screen time as well as the spread of information, and misinformation, all around the world. Media companies have recorded a general increase in screen time, gaming data usage, TV usage, and social media usage.

With nearly all activities from work to school, to socialization, communication, transaction, and relying much more on technology and its parameters, the current rhetoric is understandable that the sudden surge in Screen Time is not only unprecedented but the new normal.

Algorithms on our apps feed us more information on COVID-19 due to it being a trending topic. Where increased screen time primarily means more exposure to social media content, one could assume it means more people are being educated on prevention and safety, but it could also mean that a great percentage are being misled, because not everything is factchecked or filtered, and second-hand information has had detrimental effects on the efforts of those looking to contain the spread. WHO has coined the phenomena to be an 'infodemic' and itself has created a myth-busting 
page to corroborate their efforts against one of the most underrated consequences of the pandemic, increased screen time.

They urge people to also take matters into their own hands by only reading information from trusted sources and trusted news outlets and whatever information we do receive we can cross-check it with legitimate sources [17].

We now are not only looking to combat a pandemic that brought with it a ripple effect on the wellbeing of public health and the global economy, but also one that has redefined days to come. Moreover, it has institutionalized our future methodology in an alternated present and seeped into the way we view the world around us because of a bi-product of itself: The 'Infodemic' [12].

\section{FUNDING}

None.

\section{CONFLICT OF INTEREST}

The authors declare no conflict of interest.

\section{ACKNOWLEDGEMENTS}

None.

\section{REFERENCES}

1. Mahase E. Covid-19: WHO declares pandemic because of "alarming levels" of spread, severity, and inaction. BMJ 2020; 368: m1036.

2. Zhong $B$, Huang $Y$, Liu Q. Mental health toll from the coronavirus: Social media usage reveals Wuhan residents' depression and secondary trauma in the COVID-19 outbreak. Comput Hum 2021; 114: 106524

3. Nabity-Grover T, Cheung CMK, Thatcher JB. Inside out and outside in: How the COVID-19 pandemic affects self-disclosure on social media. Int J Inf Manage 2020; 55: 102188.

4. Shapiro MA, Hemphill L. Policy-Related communications and agenda setting: Twitter, New York Times, and the widening soapbox. SSRN Electron J 2014; Available from: http://dx.doi. org/10.2139/ssrn.2585126.
5. Bento Al, Nguyen T, Wing C, Lozano-Rojas F, Ahn YY, Simon K. Evidence from internet search data shows information-seeking responses to news of local COVID-19 cases. Proc Natl Acad Sci U S A 2020; 117(21): 11220-22.

6. Islam AKMN, Laato S, Talukder S, Sutinen E. Misinformation sharing and social media fatigue during COVID-19: An affordance and cognitive load perspective. Technol Forecast Soc Change 2020; 159: 120201

7. Jayaseelan $\mathrm{R}$, Brindha D, Waran K. Social media reigned by information or misinformation about COVID-19:A phenomenological study. SSRN Electron J 2020; Available from: https://papers.ssrn. com/abstract $=3596058$.

8. Cuan-Baltazar JY, Muñoz-Perez MJ, Robledo-Vega C, PérezZepeda MF, Soto-Vega E. Misinformation of COVID-19 on the Internet: Infodemiology study. JMIR Public Health Surveill 2020; 6(2): e18444.

9. Pennycook G, McPhetres J, Zhang Y, Lu JG, Rand DG. Fighting COVID-19 misinformation on social media: Experimental evidence for a scalable accuracy-nudge. Psychol Sci 2020; 31(7): 770-80.

10. Gao J, Zheng P, Jia Y, Chen H, Mao Y, Chen S, et al. Mental health problems and social media exposure during COVID-19 outbreak. PLoS One 2020; 15(4): e0231924.

11. Ni MY, Yang L, Leung CMC, Li N, Yao XI, Wang Y, et al. Mental health, risk factors, and social media use during the COVID-19 epidemic and cordon sanitaire among the community and health professionals in Wuhan, China: Cross-sectional survey. JMIR Ment Heal 2020; 7(5): e19009.

12. Ramazan A, Murad HR. The impact of social media on panic during the COVID-19 pandemic in Iraqi Kurdistan: Online questionnaire study. J Med Internet Res 2020; 22(5): e19556.

13. Guessoum SB, Lachal J, Radjack R, Carretier E, Minassian S, Benoit L, et al. Adolescent psychiatric disorders during the COVID-19 pandemic and lockdown. Psychiatry Res 2020; 291: 113264

14. Holmes EA, O'Connor RC, Perry VH, Tracey I, Wessely S, Arseneault $\mathrm{L}$, et al. Multidisciplinary research priorities for the COVID-19 pandemic: a call for action for mental health science. Lancet Psychiat 2020; 7(6): 547-60.

15. Sharma A, Madaan V, Petty FD. Exercise for mental health. Prim Care Companion J Clin Psychiatry 2006; 8(2): 106.

16. Nagata JM, Magid HS, Gabriel KP. Screen time for children and adolescents during the coronavirus disease 2019 pandemic. Obesity (Silver Spring) 2020; 28(9): 1582-3.

17. Wiederhold BK. Social media use during social distancing. Cyberpsychol Behav Soc Netw 2020; 23(5): 275-6. 